\title{
Presenilin: RIP and Beyond
}

\author{
Matthew R. Hass, Chihiro Sato, Raphael Kopan ", and Guojun Zhao* \\ Department of Developmental Biology, Washington University School of Medicine, Box 8103, 4566 \\ Scott Avenue, Saint Louis, Missouri, MO 63110, United States of America
}

\begin{abstract}
Over the years the presenilins (PSENs), a family of multi-transmembrane domain proteins, have been ascribed a number of diverse potential functions. Recent in vivo evidence has supported the existence of PSEN functions beyond its well-established role in regulated intramembrane proteolysis. In this review, we will briefly discuss the ability of PSEN to modulate cellular signaling pathways through $\gamma$-secretase cleavage of transmembrane proteins. Additionally, we will critically examine the proposed roles of PSEN in the regulation of $\beta$-catenin function, protein trafficking, calcium regulation, and apoptosis.
\end{abstract}

\section{Keywords}

presenilin; regulated intramembrane proteolysis; $\beta$-catenin; calcium; apoptosis

Ever since the discovery of presenilin (PSEN) mutations in families with autosomal dominant Alzheimer's disease (AD), the function of these enigmatic proteins has been the subject of intense investigation. This global effort has led to the confluence of the seemingly disparate fields of embryonic development and adult neurodegeneration as investigators discovered that PSENs formed the catalytic component of $\gamma$-secretase, a novel intramembrane aspartyl protease (along with Nicastrin (Nct), Aph-1, and Pen-2) [1]. Not only is $\gamma$-secretase involved in the proteolysis of amyloid precursor protein (APP) thereby generating the C-terminus of the pathogenic $\mathrm{A} \beta 42$ peptide, it is also responsible for the $\mathrm{S} 3$ cleavage that liberates the soluble Notch intracellular domain (NICD) to translocate to the nucleus to affect transcription of its target genes.

To date, more than fifty $\gamma$-secretase substrates have been identified[2] and it has been suggested that $\gamma$-secretase-mediated cleavage does not depend on the sequence of a type-I membrane protein, but rather on the size of its extracellular domain[3]. Additionally, it has been claimed that a few type-II transmembrane proteins and even one multipass transmembrane protein, GluR3, can become substrates of $\gamma$-secretase although these results need to be independently verified[2]. Based on this apparent promiscuity we proposed that $\gamma$-secretase may function as "the proteasome of the membrane"[4], with the important biological function of clearing protein domains from cellular membranes. For a minority of substrates, $\gamma$-secretase may play a central role in a signaling paradigm that has been termed regulated intramembrane proteolysis (RIP)[5]. RIP activates signaling pathways, such as Notch, by allowing intracellular domains

*Corresponding author: Email: E-mail: kopan@ beckermail.wustl.edu and E-mail: guojunzhao@wustl.edu, Telephone: 314-747-5520, Fax: 314-362-7058.

Publisher's Disclaimer: This is a PDF file of an unedited manuscript that has been accepted for publication. As a service to our customers we are providing this early version of the manuscript. The manuscript will undergo copyediting, typesetting, and review of the resulting proof before it is published in its final citable form. Please note that during the production process errors may be discovered which could affect the content, and all legal disclaimers that apply to the journal pertain. 
(ICDs) to translocate to the nucleus. Alternatively, RIP may turn off signaling events in which the transmembrane anchored protein is responsible for signaling and cleavage terminates the signal. For example, DCC induced neurite outgrowth is enhanced by $\gamma$-secretase inhibitors and not observed with over-expression of the DCC-ICD [6]. A third possibility is that cleavage may serve as a switch between signaling modes with the transmembrane form activating one pathway at the membrane and the soluble ICD carrying out a different function in another cellular compartment. An example of this may be ErbB4.

An extremely important point in regards to RIP, largely ignored by most investigators, is that the fate of any ICD is dependent on its N-terminus that dictates the stability of the cleaved products. According to the N-end rule, only ICDs whose N-terminus evades ubiquitination (methionine or valine) escape degradation, whereas fragments beginning in other residues undergo rapid proteasomal degradation[7-9]. Since most investigators over-express ICD fragments initiating with a methionine, "signaling" capability of $\gamma$-secretase substrates is grossly overestimated as they have artificially stabilized ICDs that would otherwise be unstable due to N-end rule degradation[10,11]. This explains the abundance of valines in the transmembrane domain (TMD) of known $\gamma$-secretase substrates and hampers efforts to identify novel substrates; ICDs with unstable N-terminal residues are difficult to detect without complete inhibition of the proteasome. This may result in a number of substrates being erroneously considered resistant to $\gamma$-secretase because their ICD fragments could not be detected due to their rapid turnover by the proteasome.

Beyond their role in $\gamma$-secretase, PSENs have been suggested to carry out a wide range of functions. However, in vivo evidence for $\gamma$-secretase-independent functions has been scant due to the dominant Notch loss-of-function phenotypes caused by PSEN deficiency in many organ systems. The moss Physcomitrella patens (P. patens), an organism that lacks Notch but contains homologues for all $\gamma$-secretase components, was used to ask if $\gamma$-secretaseindependent functions of PSENs exist in plants[12]. $P$. patens lacking the $P$. patens Presenilin (PpPS) gene displayed a number of intriguing phenotypes, which were not only rescued by expression of human PSEN but interestingly, were also rescued with catalytically dead aspartyl mutant PSEN. These phenotypes indicated the existence of a conserved, $\gamma$-secretaseindependent function of human PSEN. This conclusion is buttressed by genetic evidence in mammals for an in vivo function of PSEN beyond its role in $\gamma$-secretase. Mice deficient for both PSEN 1 and 2 display a more severe somite phenotype than that seen with Aph-1, Nct, or Pen-2 knock-out mice or in animals deficient for Notch signaling (Notch receptor double mutants or RBP-JK mutants that lack all canonical Notch signaling[13]). Specifically, mice in which Notch signaling or other members of $\gamma$-secretase have been removed were able to generate anterior somites, whereas PSEN1/PSEN2 double mutants did not, indicating that PSENs contribute to generation of anterior somites beyond their role in $\gamma$-secretase.

This review will discuss the current evidence for the diversity in PSEN function and its role in RIP. Bearing in mind the stability issue raised above, we will not attempt to address the potential functions of PSENs in regulating all of the currently known substrates as this list is continuously expanding and has been the focus of other reviews[2,14]. Instead, we will briefly discuss the role of PSENs in RIP through focusing on three well-studied substrates that represent the modes of RIP-mediated signaling mentioned above. Lastly, we will provide an overview of PSEN functions beyond its role in $\gamma$-secretase, namely in the regulation of Wnt signaling and adhesion, protein trafficking, calcium regulation, and apoptosis. A guide to the topics that we cover in this review is displayed in Figure 1. 


\section{Role of PSENs in RIP: 3 select substrates}

\section{Notch}

The best understood biological function of PSENs is their critical role in activating Notch receptors via RIP. Notch is a receptor in an evolutionarily conserved pathway mediating shortrange communication used by all metazoans at various stages of development and in the adult. Briefly, the Notch receptor binds to its ligand, presented by neighboring cells. The force involved in resolving this complex leads to shedding of the extracellular domain, allowing cleavage by $\gamma$-secretase at the cell surface or in an early endosome[15,16]. Upon cleavage, which can occur at several scissile bonds[11], NICD is released into the cytosol. Those that can escape N-end rule degradation (NICD-V starting at valine 1744) are translocated to the nucleus where they bind RBP-JK and Mastermind to activate various target genes. Although four Notch homologues (Notch 1,2,3,4) exist in mammals, and redundancy between the homologues is often seen, each Notch protein does appear to have unique functions. For instance, Notch 2 but not Notch1 is required for kidney development in mammals[17], and only mutations in Notch3 are known to cause cerebral autosomal dominant arteriopathy with subcortical infarcts and leukoencephalopathy (CADASIL) in aging humans[18]. Many additional aspects of Notch biology, regulation and the diverse physiological functions were topics of other excellent reviews and will not be discussed here[19-22].

Importantly, several human diseases and syndromes have been shown to be associated with the Notch pathway such as Alagille syndrome, aortic valve disease, and spondylocostal dysostosis as well as cancer such as T-cell acute lymphoblastic leukemia (T-ALL) and the degenerative disease CADASIL [18,23-27]. All are caused by mutations in Notch pathway components such as Notch1, 2, and 3, Jagged-1, Delta-like 3, and Lunatic fringe. Mutations of PSENs are known to not only cause familial forms of Alzheimer's disease (FAD) and affect APP cleavage, but also decrease Notch signaling to varying degrees $[28,29]$. No human PSEN mutations have been shown to contribute to any known Notch-related syndromes, arguing that $\gamma$-secretase activity is in excess relative to the RIP needs of Notch for most of the adult life. Whether Notch is involved in the pathogenesis of AD is unknown, however, Notch contributes to synaptic plasticity [30-32] and reduced Notch activity could be involved in late onset cognitive decline $[33,34]$. This ambiguity has fueled a debate in the field on whether pathogenic mutations in PSEN should be considered loss- or gain-of-function [35].

It is intriguing that PSENs also cleave Notch ligands, Jagged and Delta, following their ectodomain shedding[36-38]. Although no requirement for $\gamma$-secretase has been detected in signal-sending cells [39], methionine-stabilized Jagged-ICD and Delta-like1-ICD were observed to translocate to the nucleus and play a role in AP1 and Smad-mediated signaling, respectively[37,40], raising the possibilities that these may reflect bi-directional signaling [37]. However, since no physiological roles have been demonstrated, they are more likely to fall under the general "proteasome"-like activity of $\gamma$-secretase.

\section{APP}

APP is another well-studied substrate of $\gamma$-secretase although its biological function is still under considerable debate[41]. Shedding of the APP extracellular domain is constitutive, ligand independent and can be mediated either by the inducible $\alpha$-secretase or $\beta$-secretase. Much of APP proteolysis occurs intracellularly. Although ligands for APP have been identified $[42,43]$, they may modulate the rates of constitutive shedding of APP, in contrast to Notch ligands whose binding is an absolute prerequisite for the shedding of Notch extracellular domain. Following shedding, APP undergoes $\gamma$-secretase-mediated intramembrane cleavages at several scissile bonds, generating $\mathrm{p} 3$ peptide (if shedding was by $\alpha$-secretase) or A $\beta$ (if BACE catalyzed shedding). Both are accompanied by release of the APP intracellular domain (AICD) 
[21]. A $\beta$ species, particularly ones longer than 40 amino acids, are widely believed to be toxic, initiating the pathogenesis of $\mathrm{AD}[44]$. $\mathrm{A} \beta$-mediated toxicity may involve disruption of several biological processes, including cell surface receptor-mediated signaling, metabolism of reactive oxygen species, calcium regulation and mitochondrial function, culminating in apoptotic death of neurons[44-46]. In support of the "amyloid hypothesis", all FAD mutations in three distinct loci (PSEN1, PSEN2 and APP) increase the A $\beta 42 / 40$ ratio.

Whether AICD has physiologically important functions remains unclear. The similarity in proteolytic processing between Notch receptors and APP raised the provocative possibility that AICD acts as a transcriptional regulator, as does NICD[47]. A seminal study from Südhof's laboratory demonstrated that AICD formed a complex with the adaptor protein Fe65 and the histone acetyltransferase Tip60, driving transcription in an artificial reporter assay[48]. Although this finding was consistent with a transcriptional function for AICD, and subsequent studies have identified APP[49], GSK-3ß[50], KAI1[51], BACE[49], neprilysin[52], EGFR [53] and LRP1[54] as potential AICD targets, most utilized over-expressed (and thus, artificially stable) AICD. However, it should be noted that several of these claims have not withstood further scrutiny [55-57]. In addition, some studies used longer AICD fragments that started at the $\gamma$-site (C57/C59); such longer AICDs have never been identified by sequencing or by mass-spectrometry of immunoprecipitated cellular AICD. The controversy over the length of AICD reflects the debate concerning the exact mechanism of $\gamma$-secretase-mediated cleavage of its substrates' TMD. Most studies suggest that the first peptide bond hydrolysis takes place at the cytosolic interface ( $\varepsilon / \mathrm{S} 3$ site), similar to the ancestral bacterial GxGD type 4 prepilin peptidase[58]. Subsequently, proteolysis progresses towards the $\zeta$ - and $\gamma$-site [59-62]. Others believe that $\gamma$ and $\varepsilon / \mathrm{S} 3$ are independent from each other[63]. Until evidence emerges that C57/C59 peptides exist in vivo, the physiological relevance of artificial, longer AICD is unclear.

The reliance on non-physiological conditions to support the transcriptional role for AICD may have shifted the focus to the wrong compartment but nonetheless uncovered a biologicallyrelevant APP activity. It appears that APP and Fe65 are able to activate transcription through Tip60 in PSEN1/PSEN2-deficient cells, whereas AICD lacks this activity and actually acted as a dominant negative inhibitor to prevent signaling by holo-APP [56,64]. These studies proposed models in which the AICD needs to be associated with the membrane in order to activate signaling through $\mathrm{Fe} 65$ and Tip60 by facilitating their post-translational modifications. If true, APP may join DCC and represent the $2^{\text {nd }}$ type of signaling we mentioned in which $\gamma$ secretase-mediated cleavage turns off the signaling function of holo-APP by preventing the membrane recruitment of its intracellular interacting proteins. Alternatively, cleavage may simply facilitate the release of the activated complexes from the membrane with the AICD being targeted for rapid degradation and not providing any further function after its release. Lastly, despite years of scientific investigation, no studies have yet attempted to rescue the APP/APLP1/APLP2 phenotypes with APP molecules in which destabilizing amino acids were substituted in the TMD (as was done with Notch[65] and ErbB4[66]) to determine the contribution of the AICD to these phenotypes. Such molecules will fail to rescue APP/APLP1/ APLP2 mutants if AICD acts in the nucleus, but would not display a phenotype if APP functions as a scaffold permitting Fe65 and Tip60 modifications.

\section{ErbB4}

The identification of the receptor tyrosine kinase ErbB4 as a $\gamma$-secretase substrate[67] started a growth industry: identification of other $\gamma$-secretase substrates. Similar to Notch, and unlike APP, ErbB4 ectodomain shedding is induced upon binding of its ligand (neuregulin/heregulin) [68]. Uniquely, ErbB4 has two different juxtamembrane splice variants, one of which is resistant to ectodomain shedding thus preventing $\gamma$-secretase cleavage[69], perhaps regulating 
a $\gamma$-secretase-dependent biological function of ErbB4. Such a function was revealed by experiments demonstrating that neuregulin treatment induced growth arrest that depended upon $\gamma$-secretase activity, which is consistent with the hypothesis that cleavage of ErbB4 was important for transducing this signal[67]. Another $\gamma$-secretase-dependent function of ErbB4 is in the neuregulin-induced tyrosine phosphorylation of the E3 ligase Hdm2[70]. ErbB4ICD induces $\mathrm{Hdm} 2$ ubiquitination and turnover, resulting in enhanced p53 activity. A more direct transcriptional role for ErbB4 may result from its ability to act as a nuclear chaperone for STAT5A, facilitating its ability to activate transcription of $\beta$-casein upon neuregulin-induced cleavage[71]. Importantly, mutating the valine at the $\gamma$-secretase cleavage site in ErbB4 to isoleucine reduced ICD accumulation and prevented ErbB4 from inducing $\beta$-casein expression through STAT5A. This provided strong evidence that it was released ErbB4ICD that carried out the signaling function and not the full length protein[66]. Although the authors attributed the inhibitory effect of this point mutation to decreased $\gamma$-secretase cleavage, another likely explanation is decreased stability of the ErbB4ICD due to enhanced N-end rule degradation [11]. Interestingly, the ErbB4ICD has also been identified as a co-activator for the estrogen receptor to enhance cell growth of the breast cancer cell line T47D, which may explain why ErbB4 is implicated in breast cancer[72]. Lastly, a recent study provided convincing evidence that ErbB4ICD can transmit an important nuclear transcriptional function in vivo[73]. Neuregulin-induced cleavage of ErbB4 leads to its association with, and nuclear translocation of, the co-repressor N-CoR through the adaptor protein TAB2. ErbB4ICD/TAB2/N-CoR binding to the promoter of GFAP inhibits its expression and neural precursor differentiation into astrocytes. Most importantly, these authors provided evidence that this nuclear signaling function of ErbB4ICD occurs in vivo. They observed that GFAP expression is enhanced in ErbB4-null mouse cortex and only ErbB4 protein containing a sheddase-sensitive splice variant can reduce this enhanced astrogenesis. These studies place ErbB4 with Notch as the only known $\gamma$-secretase substrates with physiological signaling functions in vivo that are dependent upon $\gamma$-secretase cleavage. Overall, ErbB4 is a good example of the $3^{\text {rd }}$ proposed mode of RIP signaling in which the membrane bound ErbB4 and the free ErbB4ICD carry out distinct signaling functions with the former functioning to phosphorylate its substrates and the latter being involved in nuclear transcriptional complexes.

Extending the analogy to the Notch pathway, the ErbB4 ligand neuregulin is also a $\gamma$-secretase substrate[74]. As with Notch ligands, it has been suggested that the neuregulin-ICD may impact nuclear transcription through association with the zinc-finger transcription factor Eos[75]. In contrast to Notch ligands, signaling by the neuregulin-ICD may be functionally important in humans as a polymorphism in the neuregulin TMD is associated with increased risk for schizophrenia[76]. As with the man-made mutations in Notch and ErbB4, this polymorphism converts a valine to leucine at the $\gamma$-secretase cleavage site. This will likely produce a destabilized ICD due to enhanced $\mathrm{N}$-end rule degradation and thus may have reduced signaling capability. Interestingly, only $\gamma$-secretase complexes containing Aph-1B/C are involved in neuregulin cleavage as mice deficient in this protein have reduced neuregulin cleavage and exhibit neuropsychiatric abnormalities reminiscent of schizophrenia[77].

In summary, although many substrates may produce ICD fragments with biological activity, no general principle has emerged. Each of the validated substrates has its own unique regulation (force in Notch, no/little regulation in APP, uncleavable juxtamembrane exon in ErbB4). Whereas some seem to act only after cleavage (Notch) or only before it (DCC, perhaps APP), others act both as an intact protein and as an endoproteolytic C-terminal fragment (ErbB4). Clearly ICDs may act in different compartments so there is no reason to limit our imagination to the Notch precedent and assume only nuclear activity counts. Most importantly, stability is a critical variable not accounted for in the majority of studies; this must change for physiologically meaningful progress to be made. 


\section{Beyond RIP: Other emerging functions of PSEN}

As noted above, a number of $\gamma$-secretase-independent functions have been ascribed to the PSENs. In order to be completely confident that a PSEN function is $\gamma$-secretase-independent, the phenotype should be rescued in PSEN-deficient cells by the catalytically inactive PSEN mutants and not mimicked by $\gamma$-secretase inhibitors. However, both of these criteria have not always been established for many of the proposed $\gamma$-secretase-independent functions. We will discuss a few of these functions, namely regulation of $\beta$-catenin, protein trafficking, calcium regulation and apoptosis.

\section{PSEN regulation of $\beta$-catenin's roles in Wnt signaling and cell adhesion}

One well established $\gamma$-secretase-independent function of PSEN1 is its interaction with and regulation of $\beta$-catenin and other members of the armidillo protein family. Like ErbB4, $\beta$ catenin has two functions carried out at two distinct cellular locations: it is found in a membrane-associated complex with E-cadherin where it is involved in cell-cell adhesion, and as a cytoplasmic protein that translocates to the nucleus to transmit Wnt signaling. The PSEN1/ $\beta$-catenin interaction has been documented independently through a variety of methods, and the binding site for $\beta$-catenin within PSEN1 was mapped to the large cytoplasmic hydrophilic loop [78]. Initially, PSEN1 was suggested to contribute either to stabilization, to degradation or to have no effect on $\beta$-catenin levels[79-81]. However, both gain and loss of function studies in Drosophila have supported a role for PSEN as a negative regulator of $\beta$-catenin function $[82,83]$.

$\beta$-catenin is targeted for constitutive degradation by ubiquitination of a phospho-degron[84]. Phosphorylation of $\beta$-catenin is facilitated through formation of a scaffold complex comprised of Axin and APC, which allows phosphorylation by a priming kinase followed by GSK3- $\beta$ / $\alpha$. Canonical Wnt signaling blocks phosphorylation by GSK- $3 \beta$, thus sparing $\beta$-catenin from degradation, allowing nuclear entry, association with Lef/TCF and activation of targets. A number of studies have investigated the mechanism by which PSEN1 regulates $\beta$-catenin stability and the impact of this on Wnt signaling $[85,86]$. Some report that PSEN1 was able to suppress Wnt1-mediated stabilization and nuclear translocation of $\beta$-catenin[87], while others suggested that PSEN1 contributes as an alternative scaffold for $\beta$-catenin phosphorylation and degradation $[86,88,89]$. Interestingly, PSEN1 D257A mutant targeted $\beta$-catenin for turnover to a similar degree as wild-type PSEN1, further establishing this as a $\gamma$-secretase-independent function[89]. $\beta$-catenin stabilization in PSEN1-deficient skin was suggested to be physiologically important as mice deficient for PSEN1 develop skin cancers containing elevated $\beta$-catenin and its transcriptional target cyclin D1 [90]. However, this mechanism seems unlikely as later studies showed that stabilized $\beta$-catenin first induces de novo hair follicle formation[91] and then a tumor type called pilomatrichoma[92], neither seen in mice deficient for PSEN1 in the skin[90]. Furthermore, a recent study using mice in which the cytosolic loop of PSEN1 was deleted $(\triangle \mathrm{E} 10)$, which retained $\gamma$-secretase activity but lacked the putative $\beta$ catenin interaction domain, failed to develop skin cancer[93]. It is important to note that Notch1 acts as a tumor suppressor in skin[94]. The tumors that developed in the PSEN1-deficient animals may have been initiated by the reduction in Notch signaling, while progression to cancer may have been accelerated by stabilization of $\beta$-catenin. It is also possible that the stabilization of EGFR caused by PSEN1-deficiency is involved in the induction or progression of skin tumors in these mice[53,95]. The dominant role that APC/Axin complex plays in regulating $\beta$-catenin degradation makes one wonder under what circumstances the alternative degradation scaffold containing PSEN1 is involved in Wnt signaling. However, during Wnt signaling, Axin is targeted for degradation, which may allow for PSEN1 regulation of $\beta$-catenin to take on increased significance[96]. 
The cadherin protein family forms homophilic, calcium-dependent interactions that stabilize intercellular adhesions. $\beta$-catenin functions to link the cadherins to $\alpha$-catenin, which binds the actin network, thus forming a linkage between adherence junctions and the cytoskeleton, stabilizing cell-cell contacts. Another suggested role for PSEN1 is in regulating cross-talk between the cytosolic $\beta$-catenin pool (Wnt signaling) and the membrane associated $\beta$-catenin [97]. Membrane $\beta$-catenin is involved in cellular adhesion through its association with classical cadherin family members like $\mathrm{E}$ (epithelial) and $\mathrm{N}$ (neuronal)-cadherins, which are substrates for $\gamma$-secretase[97]. The presence of E-cadherin stabilized the interaction between PSEN1 and $\beta$-catenin, and in its absence, no interaction was detected between PSEN1 and $\beta$-catenin[98], questioning the importance for the PSEN1 hydrophilic loop as a stand alone interaction domain. Similarly, PSEN1 expression stabilizes the interaction between E-cadherin, $\beta$-catenin, and $\alpha$ catenin and this complex is decreased in the absence of PSEN1 resulting in decreased cellular adhesion[99]. PSEN1 was also implicated in adherence junction disassembly[100].

Additionally, N-cadherin and PSEN1 appear to increase the trafficking of each other and $\beta$ catenin to the plasma membrane to enhance cellular adhesion in neuroblastoma SH-SY5Y cells $[101,102]$. Another potential function of this complex is increased cell survival through stabilizing an interaction between N-cadherin (or E-cadherin) and PI3K to facilitate Akt activation[103,104].

The studies on PSEN1 regulation of cellular adhesion and Wnt signaling have focused on the cytosolic-loop dependent complex between classical cadherins, $\beta$-catenin, and PSEN1. The models have relied heavily upon cell culture-based evidence but compelling in vivo support for the functional importance of these interactions is still lacking. Importantly, the premise that PSEN1/ $\beta$-catenin/cadherin interactions are physiologically important was challenged by the survival and normal anatomy of mice lacking the cytosolic loop of PSEN1 $(\Delta$ E10)[93]. Although these mice display several phenotypes, none have been attributed to deficiency in $\beta$-catenin or cadherin functions; rather, they reflect the consequence of reduced $\gamma$-secretase activity and reaffirm the conclusion that Notch signaling is not as sensitive to the level of $\gamma$ secretase as $A \beta$ pathology that is extremely sensitive to it. A more thorough analysis of these mice may uncover subtle deficits that can be attributed to misregulation of $\beta$-catenin and $\mathrm{E}$ cadherin. At present, however, the lack of detectable deficits in organ development and maintenance raises doubt as to the physiological significance of the PSEN1/ $\beta$-catenin/cadherin complex.

\section{Roles of PSEN in protein trafficking}

PSENs have been suggested to play a role in regulating trafficking of several membrane proteins[105,106]; however, no clear mechanistic understanding of this function has emerged. In general, the observed effects of PSENs on trafficking can be clustered into $\gamma$-secretasedependent and independent mechanisms.

\section{Y-secretase-dependent processes}

Several laboratories observed increased cell surface accumulation of full-length APP and its C-terminal fragments in PSEN1-deficient cells or in cells expressing PSEN1 aspartate mutants $[107,108]$. PSEN1 has been shown to mediate the retention of the APP C-terminal fragments in pre-Golgi membranes, and its loss resulted in enhanced formation of APP containing vesicles [109], however, these findings were later challenged[110]. Another possible mechanism is in delayed internalization off APP[111]. Furthermore, FAD mutations in PSEN1 led to decreased release of APP-containing vesicles and reduced cell surface APP $[108,109]$. The effect of PSEN1-deficiency and FAD mutants on APP trafficking has been suggested to be due to misregulation of phospholipase D[112]. In addition, loss of PSEN severely affects the glycosylation of Nct[113-115], however, this can be viewed as a consequence of failing to form the $\gamma$-secretase complex rather than a specific role in protein maturation. 
PSEN1 also plays a unique role in regulating tyrosinase trafficking in vivo, impacting melanin synthesis in both the retinal pigment epithelium and the epidermal melanocytes[116]. In matured melanosomes, tyrosinase catalyzes the conversion of tyrosine to DOPA. PSEN1 deficiency (or treatment with $\gamma$-secretase inhibitors) leads to aberrant accumulation of tyrosinase and its $\mathrm{C}$-terminus in post-Golgi vesicles, concomitant with a significant decrease in matured melanosomes and reduction in pigmentation. Addition of L-Dopa reverses the effect, confirming it is not mediated by loss of melanocytes.

One explanation for the role of PSENs in $\gamma$-secretase-dependent protein trafficking is that some $\gamma$-secretase substrates mediate protein transport. For example, the $\gamma$-secretase substrates SorLA, Sortilin and SorCS1b[117] are members of the mammalian Vps10p sorting receptor family that bind to various cargo proteins and regulates the sorting and trafficking of a diverse array of proteins[118,119]. Therefore, some trafficking deficits in PSEN null cells may be attributed to altered metabolism of Vps10p proteins[117].

\section{Y-secretase-independent processes}

In addition to the $\gamma$-secretase-dependent processes, PSENs may regulate protein trafficking independently of their protease activity, although the underlying mechanisms remain unclear. One possible mechanism explaining $\gamma$-secretase-independent trafficking may involve the association between PSENs and several vesicle transport proteins. Examples include syntaxins $[120,121]$ and members of the Rab family of small GTPase proteins[122-124]. However, most of these interactions have been demonstrated using holo-PSENs, which accumulate after transfection but can hardly be detected in vivo. This casts doubt as to the physiological significance of these interactions.

One of the best documented $\gamma$-secretase-independent functions of PSENs in trafficking is the role of PSEN1 in the turnover of autophagic vacuoles. PSEN1 interacts with and modulates trafficking of telencephalin (TLN or ICAM-5) to affect autophagic vacuole maturation[125]. Deficiency of PSEN1 led to abnormal accumulation of TLN in autophagic vacuoles that failed to fuse with the endosome/lysosome. TLN trafficking was rescued by expression of wild type PSEN1 or PSEN1 D257A and was not mimicked by $\gamma$-secretase inhibitors, demonstrating that this is a $\gamma$-secretase-independent function of PSENs[126]. Furthermore, PSEN1-deficient neurons accumulate degradative organelles that contain alpha and beta-synuclein consistent with a physiological role for PSEN1 in the regulation of neuronal organelle trafficking[127].

Lastly, PSEN1 may regulate protein transport by modulating GSK-3 $\beta$ activity. GSK-3 $\beta$ phosphorylates kinesin light chains and causes the dissociation of kinesin-I from membranebound organelles, resulting in impaired kinesin-I-mediated transport[128]. PSEN1 was shown to promote phosphorylation and inactivation of GSK-3 $\beta$ in cell culture through PI3K/Akt signaling, an activity that was insensitive to $\gamma$-secretase inhibitors[104]. Consistent with this proposal, it has been reported that cells deficient in PSEN1, or expressing some PSEN1 FAD mutations, display impaired kinesin-I-mediated fast axonal transport associated with increase in GSK-3 $\beta$ activity $[129,130]$. However, mice in which neither GSK-3 $\beta$ nor GSK-3 $\alpha$ can be phosphorylated by Akt have no overt phenotype, again leaving open the possibility that in vivo, the ability of PSEN1 to regulate GSK-3 $\beta$ via Akt is overestimated[131]. Overall, much work remains to clarify the physiological significance of these pathways and elucidate their mechanistic detail.

\section{PSEN and calcium regulation}

In the past two decades, a number of PSEN mutations in a variety of cell lines have been shown to cause aberrant calcium homeostasis and cell death, suggesting that AD, PSEN, and calcium regulation are closely related[132]. A $\beta$ toxicity may be the primary driver of neurodegeneration 
("A $\beta$ hypothesis"). Alternatively, $A \beta$ could act synergistically with, or perhaps downstream of, disrupted calcium homeostasis ("Calcium hypothesis").

The "Calcium hypothesis" received a boost in 2008 as several groups reported $\gamma$-secretaseindependent roles for PSEN and its interacting proteins in calcium regulation. PSEN mutations have long been suggested to increase ER capacitative calcium entry through the $\mathrm{IP}_{3}$ receptor, although the underlying molecular mechanism remained unclear[133]. Recently, PSEN was reported to interact with $\mathrm{IP}_{3}$ receptors and regulate their channel activity[134]. By using patchclamp techniques in various cell lines, it was shown that the FAD mutants PSEN1 M146L and PSEN2 N141I prolonged channel opening and enhanced $\mathrm{Ca}^{2+}$ leak permeability. Interestingly, APP processing by $\gamma$-secretase was abolished in an $\mathrm{IP}_{3}$-deficient background, suggesting that calcium dysregulation may lie upstream of changes in APP metabolism. On the other hand, PSEN1 harboring a related M146V mutation was shown to accelerate the clearance of cytosolic $\mathrm{Ca}^{2+}$, most likely through direct protein-protein interactions with SERCA (sarcoplasmic ER $\mathrm{Ca}^{2+}$ ATPase) pumps[135]. The SERCA pump is the major calcium pump that removes cytosolic $\mathrm{Ca}^{2+}$. Other calcium binding proteins such as calsenilin[136], calpain[137], calmyrin [138], and sorcin[139] interact with PSEN2 and the ryanodine receptor[140] binds to PSEN1 to affect calcium regulation. These studies strongly suggest that PSEN plays an important role in calcium regulation through interactions with numerous cellular regulators of calcium flux.

An alternative perspective was recently introduced suggesting that PSEN is itself a calcium leak channel[141]. Through the use of artificial membranes containing recombinant PSEN proteins or neuronal cell cultures, PSEN was shown to form low $\mathrm{Ca}^{2+}$ conductance channels, independent of $\gamma$-secretase activity. Furthermore, introduction of PSEN1 M146V or PSEN2 N141I abolished this low-conductance channel activity and increased $\mathrm{Ca}^{2+}$ concentration in the ER[142]. One caveat however is that this activity may reside only in immature holo-PSEN proteins which under normal conditions is rarely found in cells (mature PSEN undergoes endoproteolysis). Indeed, cation permeability was not associated with PSEN expression in native ER membranes[134] (see discussion in[143]). Different channel inhibitors, cellular conditions, difference in methods for measuring $\mathrm{ER} \mathrm{Ca}^{2+}$ signaling, or a possible general weak cation channel activity of holo-PSEN[144] may have contributed to these discrepancies. More sensitive techniques to detect $\mathrm{ER} \mathrm{Ca}^{2+}$ in living cells will be needed to address these issues.

Given that not all $\mathrm{ER} \mathrm{Ca}^{2+}$ leak channels have been identified makes precise measurement of cellular calcium level difficult. A recent report has again enhanced interest in the link between calcium and AD by identifying a polymorphism in CALHM1, coding for a new $\mathrm{Ca}^{2+}$ channel [145]. This polymorphism was shown to influence calcium permeability and $A \beta$ levels, as well as increase the risk for AD. Although intracellular $\mathrm{Ca}^{2+}$ levels could be mediating their effects on $\mathrm{AD}$ via calpain[146], we await for further advances to clarify the relationship between calcium regulation, PSEN and AD.

\section{PSEN and Apoptosis}

Apoptosis has long been suggested as a mechanism contributing to selective neuronal loss, one of the major pathological features of neurodegenerative diseases[147,148]. As mutations in PSEN1/PSEN2 account for the majority of early-onset FAD cases, the role of PSENs in regulating apoptosis directly has drawn some attention. PSEN2 was first linked to apoptosis when expression of a truncated C-terminal fragment of PSEN2 rescued mouse T-cell hybridomas from T-cell receptor and Fas induced apoptosis[149]. Subsequent studies in cultured neuronal cells suggested that over-expression of PSEN1 sensitizes cells to apoptotic stimuli, although this may have reflected ER stress as PSEN1 accumulates in the ER once the available pools of Nct, Aph-1 and Pen-2 are exhausted[150]. Many FAD mutations in PSENs enhance apoptosis in cells and in mice[151-153]. For instance, primary hippocampal neurons 
from PSEN1 M146V knock-in mice displayed increased apoptosis[153]. In addition, mice with the PSEN1 M146V knock-in showed increased neuronal vulnerability to focal ischemia as compared to their wild-type controls[154]. However, primary cortical neurons from PSEN1 P264L knock-in mice did not exhibit increased degeneration, suggesting that although all FAD mutations promote $\mathrm{AD}$, not all mutations appear to enhance apoptosis[155,156].

PSENs indeed have protective functions in vivo, but these effects may be indirect. Deletion of PSEN1 in mice has been reported to result in massive loss of neural progenitor cells and neurons [157]. A study showed that PSEN1-deficient neurons displayed increased caspase-3 activation and apoptosis, which can be rescued by expression of wild-type PSEN1 but not by PSEN1 harboring FAD mutations[104]. Furthermore, conditional deletion of PSEN1/PSEN2 in adult mouse brains led to progressive loss of synapses, dendrites, and neurons[158], which suggested that loss of PSEN functions caused neuronal degeneration[35]. Likewise, reduction in Notch activity in adult flies resulted in their death $[33,34]$ arguing that loss of Notch activity may underly this phenotype. On the other hand, conditional deletion of PSEN1/PSEN2 in thymocytes increased their resistance to anti-CD3 induced apoptosis in vivo[159]. Thus, the effect of loss of PSENs on apoptosis most likely reflects their substrates or the cell type being analyzed.

PSENs have been suggested to modulate apoptosis directly through their interactions with mitochondrial associated proteins. However, confirmation that these interactions occur under physiological conditions is needed since PSENs, have been shown to interact with a great number of TMD-containing molecules, by methods developed primarily for soluble proteins (yeast two-hybrid and immunoprecipitations). Furthermore, many of these interactions were found using the C-terminus of PSEN1 as bait, based on an older topology assuming it was cytoplasmic. However, the current 9 TMD topology of PSEN suggests that the hydrophobic C-terminus is not cytosolic $[160,161]$, which challenges the physiological relevance of many of these interactions[160]. Thus, more rigorous controls will be needed to define specificity in "interactions" between PSEN1 and other multiple TMD proteins. Nevertheless, some of these interactions may play a role in pathological events. PSENs have been shown to interact directly with Bcl-2 and Bcl- $\mathrm{X}_{\mathrm{L}}$, the two major anti-apoptotic members of the Bcl-2 family[162,163]. The pro-apoptotic effect of PSEN2 over-expression is associated with down-regulation of Bcl-2 in cultured neurons[164], whereas the anti-apoptotic effect of PSEN deficiency in thymocytes is linked to the elevation of Bcl- $\mathrm{X}_{\mathrm{L}}$ expression[159]. PSENs were also reported to interact with other apoptosis related proteins such as FKBP38 (an immunophilin family member residing in the mitochondrial membrane)[165], Omi/HtrA2 [166] and PARL (PSENassociated rhomboid-like inner mitochondrial membrane protease)[167]. However, as discussed above, the significance of the PSEN association with apoptotic proteins remains to be determined.

As discussed above, PSENs may regulate apoptosis through their impact on calcium homeostasis, $A \beta$ generation, or other pathways. Both calcium and $A \beta$ have well-documented roles in apoptosis[44,168]. PSEN1 may protects neurons via its contribution to activation of the PI3K/Akt signal pathway while PSEN1 FAD mutants inhibit it[104], however, in vivo evidence has not been provided to support such a role. Moreover, loss of Pen-2[169] and Nct [170] lead to apoptosis, potentially via destabilizing PSENs[171]. Overall, PSENs regulate apoptosis through different pathways of which the underlying molecular mechanisms are just emerging.

\section{PSEN in plants}

Lastly, evidence for evolutionarily conserved $\gamma$-secretase-independent functions of PSEN have been demonstrated in vivo through the analysis of PSEN proteins and their $\gamma$-secretase partners 
in plants[12]. Deletion of PSEN in the moss P.patens affected chloroplast re-distribution in response to light, membrane/vesicle cycling and cell wall deposition, resulting in abnormally long and straight plants. As mentioned in the introduction, wild-type human PSEN1 as well as catalytically inactive PSEN1 mutants rescued the PSEN loss-of-function phenotype in $P$. patens, providing strong evidence that these functions are $\gamma$-secretase-independent.

Interestingly, ablation of Nct phenocopied the PSEN phenotype, suggesting that the association between these two proteins is ancient, perhaps preceding the establishment of enzymatic activity. Another intriguing observation is that the increased proliferation rates seen in PSEN1/ PSEN2 null MEFs were restored to normal by expression of wild-type or aspartate mutant plant PSENs, but not a mouse PSEN1 mutant in which the $\beta$-catenin binding site has been deleted $[88,90]$. These results demonstrated the existence of an evolutionarily conserved, $\gamma-$ secretase-independent function of PSEN in regulating mammalian cell proliferation[12]. It is however critically important to determine whether any $\gamma$-secretase-independent function of mammalian PSEN is physiologically important in vivo.

\section{Conclusions}

Despite being the subject of intense investigation since the discovery of PSEN1 in 1995, many outstanding questions about the biology of PSENs remain to be answered. For instance, are all type-I transmembrane proteins substrates for $\gamma$-secretase? How many of the ICDs generated by $\gamma$-secretase have additional functions, and what might those functions be? FAD mutations in PSENs not only affect the A $\beta 42 / 40$ ratio, but may also influence $\gamma$-secretase-independent functions with unknown impact on AD. How do PSENs regulate protein trafficking, and does this involve the other components of $\gamma$-secretase? The molecular mechanism underlying PSEN's role in calcium regulation, proliferation and apoptosis still needs to be further defined.

\section{Acknowledgments}

This work was supported by funding from the National Institutes of Health grants AG025973 (R.K.) and F32GM083604 (M.H.), the Washington University Alzheimer's Disease Research Center P50-AG05681 (R.K.), and Research Fellowships of the Japan Society for the Promotion of Science (C.S.).

The authors apologize for being unable to reference all of the relevant studies due to space consideration.

\section{References}

1. Steiner H. The catalytic core of gamma-secretase: presenilin revisited. Curr Alzheimer Res 2008;5:147-57. [PubMed: 18393799]

2. Beel AJ, Sanders CR. Substrate specificity of gamma-secretase and other intramembrane proteases. Cell Mol Life Sci 2008;65:1311-34. [PubMed: 18239854]

3. Struhl G, Adachi A. Requirements for Presenilin-Dependent Cleavage of Notch and Other Transmembrane Proteins. Molecular Cell 2000;6:625-63. [PubMed: 11030342]

4. Kopan R, Ilagan MX. Gamma-secretase: proteasome of the membrane? Nat Rev Mol Cell Biol 2004;5:499-504. [PubMed: 15173829]

5. Brown MS, Ye J, Rawson RB, Goldstein JL. Regulated intramembrane proteolysis: a control mechanism conserved from bacteria to humans. Cell 2000;100:391-8. [PubMed: 10693756]

6. Parent AT, Barnes NY, Taniguchi Y, Thinakaran G, Sisodia SS. Presenilin attenuates receptormediated signaling and synaptic function. J Neurosci 2005;25:1540-9. [PubMed: 15703408]

7. Varshavsky A. The N-end rule. Cell 1992;69:725-35. [PubMed: 1317266]

8. Tasaki T, Kwon YT. The mammalian N-end rule pathway: new insights into its components and physiological roles. Trends Biochem Sci 2007;32:520-8. [PubMed: 17962019]

9. Mogk A, Schmidt R, Bukau B. The N-end rule pathway for regulated proteolysis: prokaryotic and eukaryotic strategies. Trends Cell Biol 2007;17:165-72. [PubMed: 17306546] 
10. Blat Y, Meredith JE, Wang Q, Bradley JD, Thompson LA, Olson RE, et al. Mutations at the P1(') position of Notch1 decrease intracellular domain stability rather than cleavage by gamma-secretase. Biochem Biophys Res Commun 2002;299:569-73. [PubMed: 12459176]

11. Tagami S, Okochi M, Yanagida K, Ikuta A, Fukumori A, Matsumoto N, et al. Regulation of Notch Signaling by Dynamic Changes in the Precision in S3 Cleavage of Notch-1. Mol Cell Biol 2008;28:165-76. [PubMed: 17967888]

12. Khandelwal A, Chandu D, Roe CM, Kopan R, Quatrano RS. Moonlighting activity of presenilin in plants is independent of gamma-secretase and evolutionarily conserved. Proc Natl Acad Sci U S A 2007;104:13337-42. [PubMed: 17684101]

13. Huppert S, Ilagan MXG, De Strooper B, Kopan R. Analysis of Notch function in presomitic mesoderm suggests a g-secretase-independent role for presenilins in somite differentiation. Dev Cell 2005;8:677-88. [PubMed: 15866159]

14. Parks AL, Curtis D. Presenilin diversifies its portfolio. Trends Genet 2007;23:140-50. [PubMed: 17280736]

15. Kanwar R, Fortini ME. The big brain aquaporin is required for endosome maturation and notch receptor trafficking. Cell 2008;133:852-63. [PubMed: 18510929]

16. Vaccari T, Lu H, Kanwar R, Fortini ME, Bilder D. Endosomal entry regulates Notch receptor activation in Drosophila melanogaster. J Cell Biol 2008;180:755-62. [PubMed: 18299346]

17. Cheng HT, Miner JH, Lin M, Tansey MG, Roth K, Kopan R. Gamma-secretase activity is dispensable for mesenchyme-to-epithelium transition but required for podocyte and proximal tubule formation in developing mouse kidney. Development 2003;130:5031-42. [PubMed: 12952904]

18. Joutel A, Corpechot C, Ducros A, Vahedi K, Chabriat H, Mouton P, et al. Notch3 Mutations In Cadasil, a Hereditary Adult-Onset Condition Causing Stroke and Dementia. Nature 1996;383:707-10. [PubMed: 8878478]

19. Louvi A, Artavanis-Tsakonas S. Notch signalling in vertebrate neural development. Nat Rev Neurosci 2006;7:93-102. [PubMed: 16429119]

20. Radtke F, Raj K. The role of Notch in tumorigenesis: oncogene or tumour suppressor? Nat Rev Cancer 2003;3:756-67. [PubMed: 14570040]

21. Selkoe D, Kopan R. Notch and Presenilin: regulated intramembrane proteolysis links development and degeneration. Annu Rev Neurosci 2003;26:565-97. [PubMed: 12730322]

22. Bray SJ. Notch signalling: a simple pathway becomes complex. Nat Rev Mol Cell Biol 2006;7:67889. [PubMed: 16921404]

23. Weng AP, Ferrando AA, Lee W, Morris JPt, Silverman LB, Sanchez-Irizarry C, et al. Activating mutations of NOTCH1 in human T cell acute lymphoblastic leukemia. Science 2004;306:269-71. [PubMed: 15472075]

24. Oda T, Elkahloun AG, Pike BL, Okajima K, Krantz ID, Genin A, et al. Mutations in the human Jagged 1 gene are responsible for Alagille syndrome. Nat Genet 1997;16:235-42. [PubMed: 9207787]

25. Garg V. Molecular genetics of aortic valve disease. Curr Opin Cardiol 2006;21:180-4. [PubMed: 16601454]

26. Bulman MP, Kusumi K, Frayling TM, McKeown C, Garrett C, Lander ES, et al. Mutations in the human delta homologue, DLL3, cause axial skeletal defects in spondylocostal dysostosis. Nat Genet 2000;24:438-41. [PubMed: 10742114]

27. Sparrow DB, Chapman G, Wouters MA, Whittock NV, Ellard S, Fatkin D, et al. Mutation of the LUNATIC FRINGE gene in humans causes spondylocostal dysostosis with a severe vertebral phenotype. Am J Hum Genet 2006;78:28-37. [PubMed: 16385447]

28. Schroeter EH, Ilagan MXG, Brunkan AL, Hecimovic S, Li Ym, Xu M, et al. A presenilin dimer at the core of the \{gamma\}-secretase enzyme: Insights from parallel analysis of Notch 1 and APP proteolysis. PNAS 2003;100:13075-80. [PubMed: 14566063]

29. Moehlmann T, Winkler E, Xia XF, Edbauer D, Murrelll J, Capell A, et al. Presenilin-1 mutations of leucine 166 equally affect the generation of the Notch and APP intracellular domains independent of their effect on A beta(42) production. Proceedings of the National Academy of Sciences of the United States of America 2002;99:8025-30. [PubMed: 12048239]

30. Sestan N, Artavanis-Tsakonas S, Rakic P. Contact-dependent inhibition of cortical neurite growth mediated by notch signaling. Science 1999;286:741-6. [PubMed: 10531053] 
31. Wang Y, Chan SL, Miele L, Yao PJ, Mackes J, Ingram DK, et al. Involvement of Notch signaling in hippocampal synaptic plasticity. Proc Natl Acad Sci U S A 2004;101:9458-62. [PubMed: 15190179]

32. Salama-Cohen P, Arevalo MA, Grantyn R, Rodriguez-Tebar A. Notch and NGF/p75NTR control dendrite morphology and the balance of excitatory/inhibitory synaptic input to hippocampal neurones through Neurogenin 3. J Neurochem 2006;97:1269-78. [PubMed: 16539652]

33. Presente A, Andres A, Nye JS. Requirement of Notch in adulthood for neurological function and longevity. Neuroreport 2001;12:3321-5. [PubMed: 11711879]

34. Presente A, Shaw S, Nye JS, Andres AJ. Transgene-mediated RNA interference defines a novel role for notch in chemosensory startle behavior. Genesis 2002;34:165-9. [PubMed: 12324975]

35. Shen J, Kelleher RJ 3rd. The presenilin hypothesis of Alzheimer's disease: evidence for a loss-offunction pathogenic mechanism. Proc Natl Acad Sci U S A 2007;104:403-9. [PubMed: 17197420]

36. Ikeuchi T, Sisodia SS. The Notch ligands, Delta1 and Jagged2, are substrates for presenilin-dependent "gamma-secretase" cleavage. J Biol Chem 2003;278:7751-4. [PubMed: 12551931]

37. LaVoie MJ, Selkoe DJ. The Notch ligands, Jagged and Delta, are sequentially processed by alphasecretase and presenilin/gamma-secretase and release signaling fragments. J Biol Chem 2003;278:34427-37. [PubMed: 12826675]

38. Six E, Ndiaye D, Laabi Y, Brou C, Gupta-Rossi N, Israel A, et al. The Notch ligand Delta1 is sequentially cleaved by an ADAM protease and gamma-secretase. Proc Natl Acad Sci U S A 2003;100:7638-43. [PubMed: 12794186]

39. Lopez-Schier H, Johnston DS. Drosophila nicastrin is essential for the intramembranous cleavage of notch. Dev Cell 2002;2:79-89. [PubMed: 11782316]

40. Hiratochi M, Nagase H, Kuramochi Y, Koh CS, Ohkawara T, Nakayama K. The Delta intracellular domain mediates TGF-beta/Activin signaling through binding to Smads and has an important bidirectional function in the Notch-Delta signaling pathway. Nucleic Acids Res 2007;35:912-22. [PubMed: 17251195]

41. Wolfe MS, Guenette SY. APP at a glance. J Cell Sci 2007;120:3157-61. [PubMed: 17878232]

42. Ho A, Sudhof TC. Binding of F-spondin to amyloid-beta precursor protein: a candidate amyloid-beta precursor protein ligand that modulates amyloid-beta precursor protein cleavage. Proc Natl Acad Sci U S A 2004;101:2548-53. [PubMed: 14983046]

43. Ma QH, Futagawa T, Yang WL, Jiang XD, Zeng L, Takeda Y, et al. A TAG1-APP signalling pathway through Fe65 negatively modulates neurogenesis. Nat Cell Biol 2008;10:283-94. [PubMed: 18278038]

44. Small DH, Mok SS, Bornstein JC. Alzheimer's disease and Abeta toxicity: from top to bottom. Nat Rev Neurosci 2001;2:595-8. [PubMed: 11484003]

45. Yuan J, Yankner BA. Apoptosis in the nervous system. Nature 2000;407:802-9. [PubMed: 11048732]

46. Lustbader JW, Cirilli M, Lin C, Xu HW, Takuma K, Wang N, et al. ABAD directly links Abeta to mitochondrial toxicity in Alzheimer's disease. Science 2004;304:448-52. [PubMed: 15087549]

47. Annaert W, De Strooper B. Presenilins: molecular switches between proteolysis and signal transduction. Trends Neurosci 1999;22:439-43. [PubMed: 10481190]

48. Cao X, Sudhof TC. A transcriptionally [correction of transcriptively] active complex of APP with Fe65 and histone acetyltransferase Tip60. Science 2001;293:115-20. [PubMed: 11441186]

49. von Rotz RC, Kohli BM, Bosset J, Meier M, Suzuki T, Nitsch RM, et al. The APP intracellular domain forms nuclear multiprotein complexes and regulates the transcription of its own precursor. J Cell Sci 2004;117:4435-48. [PubMed: 15331662]

50. Kim HS, Kim EM, Lee JP, Park CH, Kim S, Seo JH, et al. C-terminal fragments of amyloid precursor protein exert neurotoxicity by inducing glycogen synthase kinase-3beta expression. Faseb J 2003;17:1951-3. [PubMed: 12923068]

51. Baek SH, Ohgi KA, Rose DW, Koo EH, Glass CK, Rosenfeld MG. Exchange of N-CoR corepressor and Tip60 coactivator complexes links gene expression by NF-kappa B and beta-amyloid precursor protein. Cell 2002;110:55-67. [PubMed: 12150997]

52. Pardossi-Piquard R, Petit A, Kawarai T, Sunyach C, Alves da Costa C, Vincent B, et al. Presenilindependent transcriptional control of the Abeta-degrading enzyme neprilysin by intracellular domains of betaAPP and APLP. Neuron 2005;46:541-54. [PubMed: 15944124] 
53. Zhang YW, Wang R, Liu Q, Zhang H, Liao FF, Xu H. Presenilin/gamma-secretase-dependent processing of beta-amyloid precursor protein regulates EGF receptor expression. Proc Natl Acad Sci U S A 2007;104:10613-8. [PubMed: 17556541]

54. Liu Q, Zerbinatti CV, Zhang J, Hoe HS, Wang B, Cole SL, et al. Amyloid precursor protein regulates brain apolipoprotein $\mathrm{E}$ and cholesterol metabolism through lipoprotein receptor LRP1. Neuron 2007;56:66-78. [PubMed: 17920016]

55. Chen AC, Selkoe DJ. Response to: Pardossi-Piquard et al., "Presenilin-Dependent Transcriptional Control of the Abeta-Degrading Enzyme Neprilysin by Intracellular Domains of betaAPP and APLP”. Neuron 46:541-554. [PubMed: 15944124]Neuron 2007;53:479-83. [PubMed: 17296549]

56. Hass MR, Yankner BA. A \{gamma\}-secretase-independent mechanism of signal transduction by the amyloid precursor protein. J Biol Chem 2005;280:36895-904. [PubMed: 16103124]

57. Hebert SS, Serneels L, Tolia A, Craessaerts K, Derks C, Filippov MA, et al. Regulated intramembrane proteolysis of amyloid precursor protein and regulation of expression of putative target genes. EMBO Rep 2006;7:739-45. [PubMed: 16729020]

58. LaPointe CF, Taylor RK. The type 4 prepilin peptidases comprise a novel family of aspartic acid proteases. J Biol Chem 2000;275:1502-10. [PubMed: 10625704]

59. Sastre M, Steiner H, Fuchs K, Capell A, Multhaup G, Condron MM, et al. Presenilin-dependent gamma-secretase processing of beta-amyloid precursor protein at a site corresponding to the S3 cleavage of Notch. EMBO Rep 2001;2:835-41. [PubMed: 11520861]

60. Chandu D, Huppert SS, Kopan R. Analysis of transmembrane domain mutants is consistent with sequential cleavage of Notch by gamma-secretase. J Neurochem 2006;96:228-35. [PubMed: 16300632]

61. Zhao G, Cui MZ, Mao G, Dong Y, Tan J, Sun L, et al. gamma-Cleavage is dependent on zeta-cleavage during the proteolytic processing of amyloid precursor protein within its transmembrane domain. J Biol Chem 2005;280:37689-97. [PubMed: 16157587]

62. Qi-Takahara Y, Morishima-Kawashima M, Tanimura Y, Dolios G, Hirotani N, Horikoshi Y, et al. Longer forms of amyloid beta protein: implications for the mechanism of intramembrane cleavage by gamma-secretase. J Neurosci 2005;25:436-45. [PubMed: 15647487]

63. Munter LM, Voigt P, Harmeier A, Kaden D, Gottschalk KE, Weise C, et al. GxxxG motifs within the amyloid precursor protein transmembrane sequence are critical for the etiology of Abeta42. Embo J 2007;26:1702-12. [PubMed: 17332749]

64. Cao X, Sudhof TC. Dissection of amyloid-beta precursor protein-dependent transcriptional transactivation. J Biol Chem 2004;279:24601-11. [PubMed: 15044485]

65. Huppert S, Le A, Schroeter EH, Mumm JS, Saxena MT, Milner LA, et al. Embryonic Lethality in Mice Homozygous for a Processing Deficient Allele of Notch1. Nature 2000;405:966-70. [PubMed: 10879540]

66. Vidal GA, Naresh A, Marrero L, Jones FE. Presenilin-dependent gamma -secretase processing regulates multiple ERBB4/HER4 activities. J Biol Chem 2005;280:19777-83. [PubMed: 15746097]

67. Ni CY, Murphy MP, Golde TE, Carpenter G. gamma -Secretase cleavage and nuclear localization of ErbB-4 receptor tyrosine kinase. Science 2001;294:2179-81. [PubMed: 11679632]

68. Zhou W, Carpenter G. Heregulin-dependent trafficking and cleavage of ErbB-4. J Biol Chem 2000;275:34737-43. [PubMed: 10944525]

69. Elenius K, Corfas G, Paul S, Choi CJ, Rio C, Plowman GD, et al. A novel juxtamembrane domain isoform of HER4/ErbB4. Isoform-specific tissue distribution and differential processing in response to phorbol ester. J Biol Chem 1997;272:26761-8. [PubMed: 9334263]

70. Arasada RR, Carpenter G. Secretase-dependent tyrosine phosphorylation of Mdm2 by the ErbB-4 intracellular domain fragment. J Biol Chem 2005;280:30783-7. [PubMed: 15985438]

71. Williams CC, Allison JG, Vidal GA, Burow ME, Beckman BS, Marrero L, et al. The ERBB4/HER4 receptor tyrosine kinase regulates gene expression by functioning as a STAT5A nuclear chaperone. J Cell Biol 2004;167:469-78. [PubMed: 15534001]

72. Zhu Y, Sullivan LL, Nair SS, Williams CC, Pandey AK, Marrero L, et al. Coregulation of estrogen receptor by ERBB4/HER4 establishes a growth-promoting autocrine signal in breast tumor cells. Cancer Res 2006;66:7991-8. [PubMed: 16912174] 
73. Sardi SP, Murtie J, Koirala S, Patten BA, Corfas G. Presenilin-dependent ErbB4 nuclear signaling regulates the timing of astrogenesis in the developing brain. Cell 2006;127:185-97. [PubMed: 17018285]

74. Bao J, Wolpowitz D, Role LW, Talmage DA. Back signaling by the Nrg-1 intracellular domain. J Cell Biol 2003;161:1133-41. [PubMed: 12821646]

75. Bao J, Lin H, Ouyang Y, Lei D, Osman A, Kim TW, et al. Activity-dependent transcription regulation of PSD-95 by neuregulin-1 and Eos. Nat Neurosci 2004;7:1250-8. [PubMed: 15494726]

76. Walss-Bass C, Liu W, Lew DF, Villegas R, Montero P, Dassori A, et al. A novel missense mutation in the transmembrane domain of neuregulin 1 is associated with schizophrenia. Biol Psychiatry 2006;60:548-53. [PubMed: 16730337]

77. Dejaegere T, Serneels L, Schafer MK, Van Biervliet J, Horre K, Depboylu C, et al. Deficiency of Aph1B/C-gamma-secretase disturbs Nrg1 cleavage and sensorimotor gating that can be reversed with antipsychotic treatment. Proc Natl Acad Sci U S A 2008;105:9775-80. [PubMed: 18626010]

78. Chen Q, Schubert D. Presenilin-interacting proteins. Expert Rev Mol Med 2002;4:1-18. [PubMed: 14585160]

79. Zhang Z, Hartmann H, Do VM, Abramowski D, Sturchler-Pierrat C, Staufenbiel M, et al. Destabilization of beta-catenin by mutations in presenilin-1 potentiates neuronal apoptosis. Nature 1998;395:698-702. [PubMed: 9790190]

80. Van Gassen G, Annaert W, Van Broeckhoven C. Binding partners of Alzheimer's disease proteins: are they physiologically relevant? Neurobiol Dis 2000;7:135-51. [PubMed: 10860781]

81. Murayama M, Tanaka S, Palacino J, Murayama O, Honda T, Sun X, et al. Direct association of presenilin-1 with beta-catenin. FEBS Lett 1998;433:73-7. [PubMed: 9738936]

82. Noll E, Medina M, Hartley D, Zhou J, Perrimon N, Kosik KS. Presenilin affects arm/beta-catenin localization and function in Drosophila. Dev Biol 2000;227:450-64. [PubMed: 11071766]

83. Cox RT, McEwen DG, Myster DL, Duronio RJ, Loureiro J, Peifer M. A screen for mutations that suppress the phenotype of Drosophila armadillo, the beta-catenin homolog. Genetics 2000;155:172540. [PubMed: 10924470]

84. Huang H, He X. Wnt/beta-catenin signaling: new (and old) players and new insights. Curr Opin Cell Biol 2008;20:119-25. [PubMed: 18339531]

85. Nishimura M, Yu G, Levesque G, Zhang DM, Ruel L, Chen F, et al. Presenilin mutations associated with Alzheimer disease cause defective intracellular trafficking of beta-catenin, a component of the presenilin protein complex. Nat Med 1999;5:164-9. [PubMed: 9930863]

86. Kang DE, Soriano S, Frosch MP, Collins T, Naruse S, Sisodia SS, et al. Presenilin 1 facilitates the constitutive turnover of beta-catenin: differential activity of Alzheimer's disease-linked PS1 mutants in the beta-catenin-signaling pathway. J Neurosci 1999;19:4229-37. [PubMed: 10341227]

87. Killick R, Pollard CC, Asuni AA, Mudher AK, Richardson JC, Rupniak HT, et al. Presenilin 1 independently regulates beta-catenin stability and transcriptional activity. J Biol Chem 2001;276:48554-61. [PubMed: 11606587]

88. Soriano S, Kang DE, Fu M, Pestell R, Chevallier N, Zheng H, et al. Presenilin 1 negatively regulates beta-catenin/T cell factor/lymphoid enhancer factor-1 signaling independently of beta-amyloid precursor protein and notch processing. J Cell Biol 2001;152:785-94. [PubMed: 11266469]

89. Kang DE, Soriano S, Xia X, Eberhart CG, De Strooper B, Zheng H, et al. Presenilin couples the paired phosphorylation of beta-catenin independent of axin: implications for beta-catenin activation in tumorigenesis. Cell 2002;110:751-62. [PubMed: 12297048]

90. Xia X, Qian S, Soriano S, Wu Y, Fletcher AM, Wang XJ, et al. Loss of presenilin 1 is associated with enhanced beta-catenin signaling and skin tumorigenesis. Proc Natl Acad Sci U S A 2001;98:108638. [PubMed: 11517342]

91. Lo Celso C, Prowse DM, Watt FM. Transient activation of beta-catenin signalling in adult mouse epidermis is sufficient to induce new hair follicles but continuous activation is required to maintain hair follicle tumours. Development 2004;131:1787-99. [PubMed: 15084463]

92. Gat U, DasGupta R, Degenstein L, Fuchs E. De Novo hair follicle morphogenesis and hair tumors in mice expressing a truncated beta-catenin in skin. Cell 1998;95:605-14. [PubMed: 9845363] 
93. Deng Y, Tarassishin L, Kallhoff V, Peethumnongsin E, Wu L, Li YM, et al. Deletion of presenilin 1 hydrophilic loop sequence leads to impaired gamma-secretase activity and exacerbated amyloid pathology. J Neurosci 2006;26:3845-54. [PubMed: 16597739]

94. Nicolas M, Wolfer A, Raj K, Kummer JA, Mill P, Van Noort M, et al. Notch1 functions as a tumor suppressor in mouse skin. Nat Genet 2003;33:416-21. [PubMed: 12590261]

95. Repetto E, Yoon IS, Zheng H, Kang DE. Presenilin 1 regulates epidermal growth factor receptor turnover and signaling in the endosomal-lysosomal pathway. J Biol Chem 2007;282:31504-16. [PubMed: 17716970]

96. Yamamoto H, Kishida S, Kishida M, Ikeda S, Takada S, Kikuchi A. Phosphorylation of axin, a Wnt signal negative regulator, by glycogen synthase kinase-3beta regulates its stability. J Biol Chem 1999;274:10681-4. [PubMed: 10196136]

97. Parisiadou L, Fassa A, Fotinopoulou A, Bethani I, Efthimiopoulos S. Presenilin 1 and cadherins: stabilization of cell-cell adhesion and proteolysis-dependent regulation of transcription. Neurodegener Dis 2004;1:184-91. [PubMed: 16908988]

98. Serban G, Kouchi Z, Baki L, Georgakopoulos A, Litterst CM, Shioi J, et al. Cadherins mediate both the association between PS1 and beta-catenin and the effects of PS1 on beta-catenin stability. J Biol Chem 2005;280:36007-12. [PubMed: 16126725]

99. Baki L, Marambaud P, Efthimiopoulos S, Georgakopoulos A, Wen P, Cui W, et al. Presenilin-1 binds cytoplasmic epithelial cadherin, inhibits cadherin/p120 association, and regulates stability and function of the cadherin/catenin adhesion complex. Proc Natl Acad Sci U S A 2001;98:2381-6. [PubMed: 11226248]

100. Marambaud P, Shioi J, Serban G, Georgakopoulos A, Sarner S, Nagy V, et al. A presenilin-1/gammasecretase cleavage releases the E-cadherin intracellular domain and regulates disassembly of adherens junctions. Embo J 2002;21:1948-56. [PubMed: 11953314]

101. Uemura K, Kitagawa N, Kohno R, Kuzuya A, Kageyama T, Chonabayashi K, et al. Presenilin 1 is involved in maturation and trafficking of $\mathrm{N}$-cadherin to the plasma membrane. J Neurosci Res 2003;74:184-91. [PubMed: 14515347]

102. Uemura K, Kuzuya A, Shimozono Y, Aoyagi N, Ando K, Shimohama S, et al. GSK3beta activity modifies the localization and function of presenilin 1. J Biol Chem 2007;282:15823-32. [PubMed: 17389597]

103. Baki L, Shioi J, Wen P, Shao Z, Schwarzman A, Gama-Sosa M, et al. PS1 activates PI3K thus inhibiting GSK-3 activity and tau overphosphorylation: effects of FAD mutations. Embo J 2004;23:2586-96. [PubMed: 15192701]

104. Baki L, Neve RL, Shao Z, Shioi J, Georgakopoulos A, Robakis NK. Wild-type but not FAD mutant presenilin-1 prevents neuronal degeneration by promoting phosphatidylinositol 3-kinase neuroprotective signaling. J Neurosci 2008;28:483-90. [PubMed: 18184791]

105. Sisodia SS, St George-Hyslop PH. gamma-Secretase, Notch, Abeta and Alzheimer's disease: where do the presenilins fit in? Nat Rev Neurosci 2002;3:281-90. [PubMed: 11967558]

106. Naruse S, Thinakaran G, Luo JJ, Kusiak JW, Tomita T, Iwatsubo T, et al. Effects of PS1 deficiency on membrane protein trafficking in neurons. Neuron 1998;21:1213-21. [PubMed: 9856475]

107. Leem JY, Saura CA, Pietrzik C, Christianson J, Wanamaker C, King LT, et al. A role for presenilin 1 in regulating the delivery of amyloid precursor protein to the cell surface. Neurobiology of Disease 2002;11:64-82. [PubMed: 12460547]

108. Cai D, Leem JY, Greenfield JP, Wang P, Kim BS, Wang R, et al. Presenilin-1 regulates intracellular trafficking and cell surface delivery of beta-amyloid precursor protein. J Biol Chem 2003;278:344654. [PubMed: 12435726]

109. Rechards M, Xia W, Oorschot V, van Dijk S, Annaert W, Selkoe DJ, et al. Presenilin-1-mediated retention of APP derivatives in early biosynthetic compartments. Traffic 2006;7:354-64. [PubMed: 16497228]

110. Kim J, Hamamoto S, Ravazzola M, Orci L, Schekman R. Uncoupled packaging of amyloid precursor protein and presenilin 1 into COPII vesicles. J Biol Chem. 2004

111. Kaether C, Lammich S, Edbauer D, Ertl M, Rietdorf J, Capell A, et al. Presenilin-1 affects trafficking and processing of $\{$ beta\}APP and is targeted in a complex with nicastrin to the plasma membrane. J Cell Biol 2002;158:551-61. [PubMed: 12147673] 
112. Cai D, Zhong M, Wang R, Netzer WJ, Shields D, Zheng H, et al. Phospholipase D1 corrects impaired betaAPP trafficking and neurite outgrowth in familial Alzheimer's disease-linked presenilin-1 mutant neurons. Proc Natl Acad Sci U S A 2006;103:1936-40. [PubMed: 16449385]

113. Leem JY, Vijayan S, Han P, Cai D, Machura M, Lopes KO, et al. Presenilin 1 is required for maturation and cell surface accumulation of nicastrin. J Biol Chem 2002;277:19236-40. [PubMed: 11943765]

114. Chen F, Tandon A, Sanjo N, Gu YJ, Hasegawa H, Arawaka S, et al. Presenilin 1 and presenilin 2 have differential effects on the stability and maturation of nicastrin in Mammalian brain. J Biol Chem 2003;278:19974-9. [PubMed: 12646573]

115. Herreman A, Van Gassen G, Bentahir M, Nyabi O, Craessaerts K, Mueller U, et al. gamma-Secretase activity requires the presenilin-dependent trafficking of nicastrin through the Golgi apparatus but not its complex glycosylation. J Cell Sci 2003;116:1127-36. [PubMed: 12584255]

116. Wang R, Tang P, Wang P, Boissy RE, Zheng H. Regulation of tyrosinase trafficking and processing by presenilins: Partial loss of function by familial Alzheimer's disease mutation. PNAS 2006;103:353-8. [PubMed: 16384915]

117. Andersen OM, Reiche J, Schmidt V, Gotthardt M, Spoelgen R, Behlke J, et al. Neuronal sorting protein-related receptor sorLA/LR11 regulates processing of the amyloid precursor protein. Proc Natl Acad Sci U S A 2005;102:13461-6. [PubMed: 16174740]

118. Nyborg AC, Ladd TB, Zwizinski CW, Lah JJ, Golde TE. Sortilin, SorCS1b, and SorLA Vps10p sorting receptors, are novel gamma-secretase substrates. Mol Neurodegener 2006;1:3. [PubMed: 16930450]

119. Bohm C, Seibel NM, Henkel B, Steiner H, Haass C, Hampe W. SorLA signaling by regulated intramembrane proteolysis. J Biol Chem 2006;281:14547-53. [PubMed: 16531402]

120. Smith SK, Anderson HA, Yu G, Robertson AG, Allen SJ, Tyler SJ, et al. Identification of syntaxin $1 \mathrm{~A}$ as a novel binding protein for presenilin-1. Brain Res Mol Brain Res 2000;78:100-7. [PubMed: 10891589]

121. Suga K, Tomiyama T, Mori H, Akagawa K. Syntaxin 5 interacts with presenilin holoproteins, but not with their $\mathrm{N}$ - or C-terminal fragments, and affects beta-amyloid peptide production. Biochem J 2004;381:619-28. [PubMed: 15109302]

122. Scheper W, Zwart R, Baas F. Rab6 membrane association is dependent of Presenilin 1 and cellular phosphorylation events. Brain Res Mol Brain Res 2004;122:17-23. [PubMed: 14992812]

123. Kametani F, Usami M, Tanaka K, Kume H, Mori H. Mutant presenilin (A260V) affects Rab8 in PC12D cell. Neurochem Int 2004;44:313-20. [PubMed: 14643748]

124. Dumanchin C, Czech C, Campion D, Cuif MH, Poyot T, Martin C, et al. Presenilins interact with Rab11, a small GTPase involved in the regulation of vesicular transport. Hum Mol Genet 1999;8:1263-9. [PubMed: 10369872]

125. Annaert WG, Esselens C, Baert V, Boeve C, Snellings G, Cupers P, et al. Interaction with telencephalin and the amyloid precursor protein predicts a ring structure for presenilins. Neuron 2001;32:579-89. [PubMed: 11719200]

126. Esselens C, Oorschot V, Baert V, Raemaekers T, Spittaels K, Serneels L, et al. Presenilin 1 mediates the turnover of telencephalin in hippocampal neurons via an autophagic degradative pathway. J Cell Biol 2004;166:1041-54. [PubMed: 15452145]

127. Wilson CA, Murphy DD, Giasson BI, Zhang B, Trojanowski JQ, Lee VM. Degradative organelles containing mislocalized alpha-and beta-synuclein proliferate in presenilin-1 null neurons. J Cell Biol 2004;165:335-46. [PubMed: 15123735]

128. Morfini G, Szebenyi G, Elluru R, Ratner N, Brady ST. Glycogen synthase kinase 3 phosphorylates kinesin light chains and negatively regulates kinesin-based motility. Embo J 2002;21:281-93. [PubMed: 11823421]

129. Pigino G, Morfini G, Pelsman A, Mattson MP, Brady ST, Busciglio J. Alzheimer's presenilin 1 mutations impair kinesin-based axonal transport. J Neurosci 2003;23:4499-508. [PubMed: 12805290]

130. Lazarov O, Morfini GA, Pigino G, Gadadhar A, Chen X, Robinson J, et al. Impairments in fast axonal transport and motor neuron deficits in transgenic mice expressing familial Alzheimer's disease-linked mutant presenilin 1. J Neurosci 2007;27:7011-20. [PubMed: 17596450] 
131. McManus EJ, Sakamoto K, Armit LJ, Ronaldson L, Shpiro N, Marquez R, et al. Role that phosphorylation of GSK3 plays in insulin and Wnt signalling defined by knockin analysis. Embo J 2005;24:1571-83. [PubMed: 15791206]

132. Bezprozvanny I, Mattson MP. Neuronal calcium mishandling and the pathogenesis of Alzheimer's disease. Trends Neurosci 2008;31:454-63. [PubMed: 18675468]

133. Etcheberrigaray R, Hirashima N, Nee L, Prince J, Govoni S, Racchi M, et al. Calcium responses in fibroblasts from asymptomatic members of Alzheimer's disease families. Neurobiol Dis 1998;5:3745. [PubMed: 9702786]

134. Cheung KH, Shineman D, Muller M, Cardenas C, Mei L, Yang J, et al. Mechanism of Ca2+ disruption in Alzheimer's disease by presenilin regulation of $\operatorname{Ins} \mathrm{P}(3)$ receptor channel gating. Neuron 2008;58:871-83. [PubMed: 18579078]

135. Green KN, Demuro A, Akbari Y, Hitt BD, Smith IF, Parker I, et al. SERCA pump activity is physiologically regulated by presenilin and regulates amyloid beta production. J Cell Biol 2008;181:1107-16. [PubMed: 18591429]

136. Buxbaum JD, Choi EK, Luo Y, Lilliehook C, Crowley AC, Merriam DE, et al. Calsenilin: a calciumbinding protein that interacts with the presenilins and regulates the levels of a presenilin fragment. Nat Med 1998;4:1177-81. [PubMed: 9771752]

137. Shinozaki K, Maruyama K, Kume H, Tomita T, Saido TC, Iwatsubo T, et al. The presenilin 2 loop domain interacts with the mu-calpain C-terminal region. Int J Mol Med 1998;1:797-9. [PubMed: 9852298]

138. Stabler SM, Ostrowski LL, Janicki SM, Monteiro MJ. A myristoylated calcium-binding protein that preferentially interacts with the Alzheimer's disease presenilin 2 protein. J Cell Biol 1999;145:127792. [PubMed: 10366599]

139. Pack-Chung E, Meyers MB, Pettingell WP, Moir RD, Brownawell AM, Cheng I, et al. Presenilin 2 interacts with sorcin, a modulator of the ryanodine receptor. Journal of Biological Chemistry 2000;275:14440-5. [PubMed: 10748169]

140. Chan SL, Mayne M, Holden CP, Geiger JD, Mattson MP. Presenilin-1 mutations increase levels of ryanodine receptors and calcium release in PC12 cells and cortical neurons. J Biol Chem 2000;275:18195-200. [PubMed: 10764737]

141. Tu H, Nelson O, Bezprozvanny A, Wang Z, Lee SF, Hao YH, et al. Presenilins form ER Ca2+ leak channels, a function disrupted by familial Alzheimer's disease-linked mutations. Cell 2006;126:981-93. [PubMed: 16959576]

142. Nelson O, Tu H, Lei T, Bentahir M, de Strooper B, Bezprozvanny I. Familial Alzheimer diseaselinked mutations specifically disrupt $\mathrm{Ca} 2+$ leak function of presenilin 1 . J Clin Invest 2007;117:1230-9. [PubMed: 17431506]

143. Kasri NN, Kocks SL, Verbert L, Hebert SS, Callewaert G, Parys JB, et al. Up-regulation of inositol 1,4,5-trisphosphate receptor type 1 is responsible for a decreased endoplasmic-reticulum $\mathrm{Ca} 2+$ content in presenilin double knock-out cells. Cell Calcium 2006;40:41-51. [PubMed: 16675011]

144. Malin SA, Guo WX, Jafari G, Goate AM, Nerbonne JM. Presenilins upregulate functional K+ channel currents in mammalian cells. Neurobiol Dis 1998;4:398-409. [PubMed: 9666479]

145. Dreses-Werringloer U, Lambert JC, Vingtdeux V, Zhao H, Vais H, Siebert A, et al. A polymorphism in CALHM1 influences Ca2+ homeostasis, Abeta levels, and Alzheimer's disease risk. Cell 2008;133:1149-61. [PubMed: 18585350]

146. Higuchi M, Iwata N, Saido TC. Understanding molecular mechanisms of proteolysis in Alzheimer's disease: progress toward therapeutic interventions. Biochim Biophys Acta 2005;1751:60-7. [PubMed: 16054018]

147. Cotman CW, Su JH. Mechanisms of neuronal death in Alzheimer's disease. Brain Pathol 1996;6:493-506. [PubMed: 8944319]

148. Cotman CW, Anderson AJ. A potential role for apoptosis in neurodegeneration and Alzheimer's disease. Mol Neurobiol 1995;10:19-45. [PubMed: 7598831]

149. Vito P, Lacana E, D'Adamio L. Interfering with apoptosis: $\mathrm{Ca}(2+)$-binding protein ALG-2 and Alzheimer's disease gene ALG-3. Science 1996;271:521-5. [PubMed: 8560270] 
150. Thinakaran G, Borchelt DR, Lee MK, Slunt HH, Spitzer L, Kim G, et al. Endoproteolysis of presenilin 1 and accumulation of processed derivatives in vivo. Neuron 1996;17:181-90. [PubMed: 8755489]

151. Wolozin B, Iwasaki K, Vito P, Ganjei JK, Lacana E, Sunderland T, et al. Participation of presenilin 2 in apoptosis: enhanced basal activity conferred by an Alzheimer mutation. Science 1996;274:1710-3. [PubMed: 8939861]

152. Janicki S, Monteiro MJ. Increased apoptosis arising from increased expression of the Alzheimer's disease-associated presenilin-2 mutation (N141I). J Cell Biol 1997;139:485-95. [PubMed: 9334350]

153. Guo Q, Sebastian L, Sopher BL, Miller MW, Ware CB, Martin GM, et al. Increased vulnerability of hippocampal neurons from presenilin-1 mutant knock-in mice to amyloid beta-peptide toxicity: central roles of superoxide production and caspase activation. J Neurochem 1999;72:1019-29. [PubMed: 10037473]

154. Mattson MP, Zhu H, Yu J, Kindy MS. Presenilin-1 mutation increases neuronal vulnerability to focal ischemia in vivo and to hypoxia and glucose deprivation in cell culture: involvement of perturbed calcium homeostasis. J Neurosci 2000;20:1358-64. [PubMed: 10662826]

155. Siman R, Reaume AG, Savage MJ, Trusko S, Lin YG, Scott RW, et al. Presenilin-1 P264L knockin mutation: differential effects on abeta production, amyloid deposition, and neuronal vulnerability. J Neurosci 2000;20:8717-26. [PubMed: 11102478]

156. Siman R, Flood DG, Thinakaran G, Neumar RW. Endoplasmic reticulum stress-induced cysteine protease activation in cortical neurons: effect of an Alzheimer's disease-linked presenilin-1 knockin mutation. J Biol Chem 2001;276:44736-43. [PubMed: 11574534]

157. Shen J, Bronson RT, Chen DF, Xia W, Selkoe DJ, Tonegawa S. Skeletal and CNS defects in Presenilin-1-deficient mice. Cell 1997;89:629-39. [PubMed: 9160754]

158. Saura CA, Choi SY, Beglopoulos V, Malkani S, Zhang D, Shankaranarayana Rao BS, et al. Loss of presenilin function causes impairments of memory and synaptic plasticity followed by agedependent neurodegeneration. Neuron 2004;42:23-36. [PubMed: 15066262]

159. Maraver A, Tadokoro CE, Badura ML, Shen J, Serrano M, Lafaille JJ. Effect of presenilins in the apoptosis of thymocytes and homeostasis of CD8+ T cells. Blood 2007;110:3218-25. [PubMed: 17626841]

160. Spasic D, Tolia A, Dillen K, Baert V, De Strooper B, Vrijens S, et al. Presenilin-1 maintains a ninetransmembrane topology throughout the secretory pathway. J Biol Chem 2006;281:26569-77. [PubMed: 16846981]

161. Sato C, Takagi S, Tomita T, Iwatsubo T. The C-terminal PAL motif and transmembrane domain 9 of presenilin 1 are involved in the formation of the catalytic pore of the gamma-secretase. J Neurosci 2008;28:6264-71. [PubMed: 18550769]

162. Alberici A, Moratto D, Benussi L, Gasparini L, Ghidoni R, Gatta LB, et al. Presenilin 1 protein directly interacts with Bcl-2. J Biol Chem 1999;274:30764-9. [PubMed: 10521466]

163. Passer BJ, Pellegrini L, Vito P, Ganjei JK, D'Adamio L. Interaction of Alzheimer's presenilin-1 and presenilin-2 with Bcl-X(L). A potential role in modulating the threshold of cell death. J Biol Chem 1999;274:24007-13. [PubMed: 10446169]

164. Araki W, Yuasa K, Takeda S, Takeda K, Shirotani K, Takahashi K, et al. Pro-apoptotic effect of presenilin 2 (PS2) overexpression is associated with down-regulation of $\mathrm{Bcl}-2$ in cultured neurons. J Neurochem 2001;79:1161-8. [PubMed: 11752057]

165. Wang HQ, Nakaya Y, Du Z, Yamane T, Shirane M, Kudo T, et al. Interaction of presenilins with FKBP38 promotes apoptosis by reducing mitochondrial Bcl-2. Hum Mol Genet 2005; 14:1889-902. [PubMed: 15905180]

166. Gupta S, Singh R, Datta P, Zhang Z, Orr C, Lu Z, et al. The C-terminal tail of presenilin regulates Omi/HtrA2 protease activity. J Biol Chem 2004;279:45844-54. [PubMed: 15294909]

167. Pellegrini L, Passer BJ, Canelles M, Lefterov I, Ganjei JK, Fowlkes BJ, et al. PAMP and PARL, two novel putative metalloproteases interacting with the $\mathrm{COOH}$-terminus of Presenilin-1 and -2 . J Alzheimers Dis 2001;3:181-90. [PubMed: 12214059]

168. Orrenius S, Zhivotovsky B, Nicotera P. Regulation of cell death: the calcium-apoptosis link. Nat Rev Mol Cell Biol 2003;4:552-65. [PubMed: 12838338] 
169. Campbell WA, Yang H, Zetterberg H, Baulac S, Sears JA, Liu T, et al. Zebrafish lacking Alzheimer presenilin enhancer 2 (Pen-2) demonstrate excessive p53-dependent apoptosis and neuronal loss. J Neurochem 2006;96:1423-40. [PubMed: 16464238]

170. Nguyen V, Hawkins C, Bergeron C, Supala A, Huang J, Westaway D, et al. Loss of nicastrin elicits an apoptotic phenotype in mouse embryos. Brain Res 2006;1086:76-84. [PubMed: 16626651]

171. Dunys J, Kawarai T, Sevalle J, Dolcini V, George-Hyslop PS, Da Costa CA, et al. p53-Dependent Aph-1 and Pen-2 anti-apoptotic phenotype requires the integrity of the gamma-secretase complex but is independent of its activity. J Biol Chem 2007;282:10516-25. [PubMed: 17276981] 


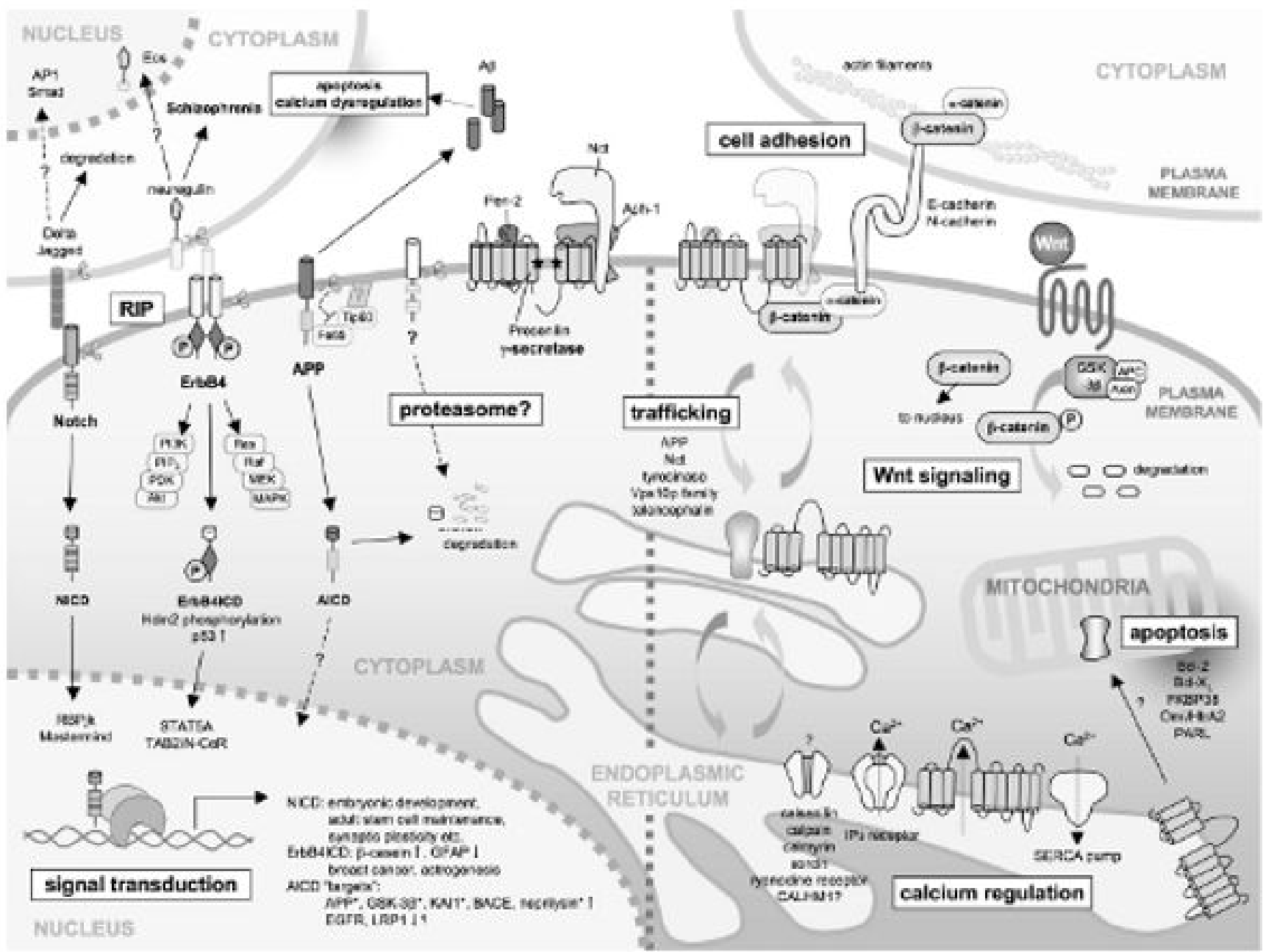

Figure 1.

Presenilin: RIP and beyond. Left: $\gamma$-secretase-dependent functions of presenilin (PSEN). PSEN $/ \gamma$-secretase modulates cellular signaling pathways through RIP. Asterisks indicate target genes that are under debate as discussed in the text. PSEN $/ \gamma$-secretase may also function as a proteasome. Right: Other emerging functions of PSEN. PSEN is also implicated in Wnt signaling, cell adhesion, trafficking, calcium regulation and apoptosis. See the corresponding sections for detail. AbbreviationsA $\beta$; amyloid $\beta$ peptide, AICD; APP intracellular domain, APP; Amyloid $\beta$ precursor protein, ErbB4ICD; ErbB4 intracellular domain, Nct; Nicastrin, NICD; Notch intracellular domain, RIP; regulated intramembrane proteolysis, SERCA; sarcoplasmic ER $\mathrm{Ca}^{2+}$ ATPase. 